\title{
The Essex Institute and Business Records
}

THOse who have been in any way interested in the Essex Institute, or have used their already valuable collections of shipping papers, will welcome the addition of this important institution to the group of libraries and similar collecting agencies that are endeavoring to accumulate and preserve the materials for business history. Announcement of this new step on the part of the Institute has recently been made, and we can perhaps do no better than to reproduce part of the statement of Mr. Henry Belknap, the secretary of the Institute, as revealed in the January 17 th issue of the Salem Evening News.

"To widen its scope of usefulness to students of business history, the Essex Institute is seeking to enlarge its collection of records of Essex County business activities. In making its appeal for old business books and papers, Mr. Belknap said: "The record of these industries, some of which had their beginning with the founding of the first settlements on this continent, trace not only the business history of Essex County but the economic development of other sections of the country. Surplus capital made here financed expansion of new areas and this material is extremely valuable to students of economics and to writers on economic subjects.'"

The Institute library already has considerable documentary material on the early business history of the country, but it is most anxious to widen the scope of its collection and hence add to its value to the student of economic conditions. The Institute, like the Business Historical Society, is only too glad to be consulted when manuscripts and records are to be discarded, in order to save them from destruction and to make them available for study and research.

\section{In ftlemoriam}

Is the passing of George Fisher Baker, this Society has suffered a great loss. The quiet, serene man who had directed and guided American finance for over half a century, finished his work on May 2, at the age of ninety-one. Mr. Baker's vision of a great business and industrial philosophy will perpetuate his memory in the world of business; his endowments to educational institutions and philanthropic movements will be enduring memorials to his devotion to ideals. 